一原 著一

\title{
トランスフェリン・レセプターの新しい精製方法と その生化学的性質
}

\author{
田口 正男 \\ 日本医科大学生化学第 2 教室
}

\section{An improved purification of human placental transferrin receptor and biochemical properties of the receptor}

\author{
Masao Taguchi \\ The Second Department of Biochemistry, Nippon Medical School
}

\begin{abstract}
An improved method for the purification of human placental transferrin receptor (Tf-R) was developed. Fresh human placenta was homogenized in cold acetone and the acetone powder was prepared. After the acetone powder had been washed with HEPES buffer, the insoluble proteins containing Tf-R were separated by centrifugation and dissolved in Emulgen 109P-containing buffer. Tf-R was collected by affinity binding to Tf-Sepharose and extracted by consecutive treatment with 4 different kinds of buffers. Tf-R was eluted by buffer $\mathrm{C}(2 \mathrm{M} \mathrm{KCl})$ and buffer $\mathrm{D}(0.5 \mathrm{M} \mathrm{NaSCN})$. Tf-R was characterized as a $90-\mathrm{kDa}$ monomer on gradient SDS-PAGE (4-20\%) in the presence of 2-mercaptoethanol. Though there were several minor bands of 180-and above $205-\mathrm{kDa}$, all these bands were confirmed as Tf-R by Western blotting using an anti-Tf-R monoclonal antibody (OKT 9). The apparent molecular weights, measured by HPLC using a TSK-G $3,000 \mathrm{SW}$ column, demonstrated that Tf-Rs eluted with buffer $\mathrm{C}$ were approximately $370-, 500$ - and above $500-\mathrm{kDa}$, but only a peak of above $500-\mathrm{kDa}$ was found in Tf-R eluted with buffer $\mathrm{D}$. Although the polymers of $\mathrm{Tf}-\mathrm{R}$ with moleculer weight of above $500-\mathrm{kDa}$ were resistant to trypsin digestion, the Tf-R of $370-\mathrm{kDa}$ was resistant to the enzyme only when it conjugated to the diferric Tf. The stability of the polymers of above $500-\mathrm{kDa}$ to trypsin digestion suggested an advantage for the repeated use of $\mathrm{Tf}-\mathrm{R}$ in the endocytosis of diferric $\mathrm{Tf}$, which was performed by the translocation of Tf-R between cell surface and intracellular vesicles.
\end{abstract}

Key words: human transferrin receptor, purification and biochemical properties, polymer formation

\section{緒 言}

トランスフェリン(Tf)は, 分子量 $80-\mathrm{kDa}$ の糖タン パク質であり，その主な生理機能は鉄の運搬である. 鉄イオンの細胞内への取り込みは, Tf と鉄イオン 2 原 子が結合した diferric Tfが細胞表面にある糖タンパ ク質であるトランスフェリン・レセプター（Tf-R）と 特異的に結合し，結合体として細胞内へエンドサイ トーシスされることが種々の細胞で証明されてい $3^{1-10)}$.Tf-R は，分子量 $190-\mathrm{kDa}$ の糖タンパク質で分 子量 95-kDa の相同の 2 つの一量体より構成され, 一

Correspondence to Masao Taguchi, Depertment of Biochemistry, Nippon Medical School, 1-1-5 Sendagi, Bunkyo-ku, Tokyo 113, Japan
量体あたり 1 分子の diferric Tf と結合することがで きる11-13). Diferric Tfは receptor-mediated endocytosisにより細胞内に取り込まれ endosome (endocytotic vesicle) を形成する ${ }^{1 \sim 10)}$. Specific proton pump $^{14,15)}$ により endosome 内の $\mathrm{pH}$ が低下すると Tf より鉄の解離が起こる：しかし，Tf-R と apo-Tf との 解離は起こらず, 細胞表面に再度露出し, 細胞外液の むつ中性領域の $\mathrm{pH}$ にさらされてはじめて両者の解離 は起こる ${ }^{1,5,9)}$. 細胞内で解離された鉄は heme 合成の 原料となるか，または ferritin として貯蔵される ${ }^{9,16)}$. また，細胞表面で apo-Tfを解離したTf-Rは，再び receptor-mediated endocytosis を繰り返す. 同様に, 細胞表面で解離された apo-Tf オンと結合し diferric Tf となり鉄運搬に再利用され 
る.

Tf-Rの存在が最初に証明されたのは網赤血球であ るが17,18)，その後ヒト胎盤䄉毛細胞をはじめとして 種々の細胞で, その存在が確認された 11,13,19 23). Selig-

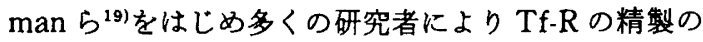
試みがなされてきた。しかし，この精製方法はきわめ て複雜であり，収量の面からも十分とは考えにくい， そのため，種々の改良がなされたが，いまた満足いく 方法には至らなかった ${ }^{12,24 ~ 26)}$. そこで著者は，アセ卜 ン処理を利用し，さらにTf-Rの生化学的特徵である Tf への親和性を応用し，結合活性を有した Tf-R へ精 製法を開発した。ささらに得られた Tf-Rの生化学的性 質を検討したので報告する。

\section{研究材料および方法}

(1) 材料

1）ヒト胎盤

正期正常妊娠の分娩後 30 分以内の新鮮なとト胎盤 を用いた。

\section{2) 試薬}

CNBr-activated Sepharose $4 \mathrm{~B}$ は, Pharmacia Fine Chemical 社, PMSF (phenyl-methyl-sulfonyl fluoride), Soybean Trypsin inhibitor, high molecular weight standard mixture, Anti-mouse Ig-G biotin conjugate, Avidine-labeled horseradish peroxidase, 3,3'-diaminobenzidine (tetrahydrochloride) は, Sigma Chemical 社, 電気泳動用グラシシェントゲル SDS-PAGE プレート4/20は, 第一化学薬品, Emulgen $109 \mathrm{P}$ は, 花王, desferrioxamine は, CIBA. GEIGY 社, 抗 Tf-R モノクロナール抗体 NU-tfR1 は, 生化学工業, 抗 Tf-Rモノクロナール抗体 OKT 9 は, Orth Diagnostic System 社, Trypsin (Bovine Pancreas）は, P.L Bio-chemical 社, TSK-G 3,000 SW カラム $(7.5 \mathrm{mmID} \times 60 \mathrm{~cm})$ は, 東洋曹達工業, Gel Filtration Standard は, Bio-Rad 社よりそれぞれ購入 した。 その他の試薬は市販の特級品を用いた。

(2) 方法

1）ヒト血清 $\operatorname{Tf}$ の分離精製

ヒト血清より吉野らの方法 ${ }^{27} に よ り \mathrm{Tf}$ を分離精製 した。精製 Tfはsodium dodecyl sulfate polyacrylamide gel electrophoresis (SDS-PAGE) により, 80-kDa の単一バンドであることを確認した。

2）二トリロ三酢酸第二鉄（Fe-NTA）の作製

粟井らの方法 ${ }^{28}$ にしたがってニトリロ三酢酸三ナト
リウム（NTA）より黒褐色の Fe-NTAを得た.

3) Diferric Tf-Sepharose $の$ 作製

CNBr-activated Sepharose 4 B $8.6 \mathrm{~g}(30 \mathrm{ml}) に$ diferric Tf $10 \mathrm{mg} / \mathrm{m} l$ の濃度で製品指示書にした がってカップリングさせた。最終段階で非特異的に吸 着した Tf を除去するため酸性緩衝液で洗浄した。 そ のためTf-Sepharoseはアポ化されているので FeNTAを加え, diferric Tf-Sepharose とした.

\section{4) Tf-R の精製}

\section{（i）アセトンパウダーの作成}

Hudgin ら ${ }^{23,299}$ の方法にしたがってアセトンパウ ダーを作製した. 分婏後 30 分以内の新鮮なヒト胎盤組 織から羊膜, 脐帯を除去後, 胎盤実質部 $160 \mathrm{~g}$ を細切 L, $0.1 \mathrm{~mol} / l$ Tris 緩衝液 $(0.1 \mathrm{~mol} / l$ Tris, $\mathrm{pH} 7.4$, $0.01 \mathrm{~mol} / l$ EDTA, $0.2 \mathrm{~mol} / l \mathrm{NaCl}, 50 \mu \mathrm{mol} / l$ PMSF, $2 \mathrm{mg} / l$ Trypsin inhibitor)にてすみやかに洗 浄した。ついでー $20^{\circ} \mathrm{C}$ に冷却した 5 倍量 $(\mathrm{v} / \mathrm{w})$ のアセ トンを加党, 30 秒間, 2 回ワーリンダブレンダーにて ホモジナイズし，繋濁液を滤過し，濾液を除去した。 この操作を 2 回繰り返し, 沈澱を室温に 30 分間放置す るとパウダー状になった。

（ii）アセトンパウダーの可溶化

アセトンパウダーを約 20 倍量 $(\mathrm{v} / \mathrm{w})$ の $50 \mathrm{mmol} / \mathrm{l}$

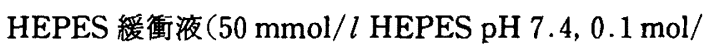
$l \mathrm{KCl}, 50 \mu \mathrm{mol} / l \mathrm{PMSF}, 2 \mathrm{mg} / l$ Trypsin inhibitor) に懸濁し， $10,000 \times \mathrm{g} 10$ 分間遠心分離し沈渣を集め た。この操作を 3 回繰り返しアセトンパウダーを十分 洗浄した.ついでアセトンパウダーを $20 \mathrm{~g} / \mathrm{l}$ Emulgen $109 \mathrm{P}$ を含む $50 \mathrm{mmol} / l \mathrm{HEPES}$ 楥衝液にて再懸濁 し, 90 秒間フルスピードでワーリングブレンダーにて 可溶化した。ささらに $4{ }^{\circ} \mathrm{C} ， 1$ 時間静かに擤拌し可溶化 を終了した。 その後 $10,000 \times \mathrm{g} 30$ 分間遠心分離し上清 を集め,この上清を $1 \mathrm{~g} / l$ Emulgen $109 \mathrm{P}$ を含む 50 $\mathrm{mmol} / l$ HEPES で一晚透析した。

(iii) Tf-Rの溶出

透析上清を diferric Tf-Sepharose と室温で 1 時間 捊置した後に，カラム $(2 \mathrm{cmID} \times 25 \mathrm{~cm})$ に重層し, 1 $\mathrm{g} / \mathrm{l}$ Emulgen $109 \mathrm{P}$ 含む $50 \mathrm{mM}$ HEPESにて十分 に洗浄した. ついで以下の 4 種類の buffer 各 $50 \mathrm{ml}$ を 順次カラムに負荷した。

i) buffer $\mathrm{A}: 0.1 \mathrm{~mol} / l$ sodium citrate $\mathrm{pH} 5.0$, $1 \mathrm{~g} / l$ Emulgen $109 \mathrm{P}, 50 \mathrm{mg} / l$ desferrioxamine, 50 $\mu \mathrm{mol} / l \mathrm{PMSF}, 2 \mathrm{mg} / l$ Trypsin inhibitor

ii) buffer $B: 50 \mathrm{mmol} / l$ HEPES $\mathrm{pH} 7.4,100$ 
$\mathrm{mmol} / l \mathrm{KCl}, 1 \mathrm{~g} / l$ Emulgen $109 \mathrm{P}, 50 \mathrm{mg} / l$ desferrioxamine, $50 \mu \mathrm{mol} / l \mathrm{PMSF}, 2 \mathrm{mg} / l$ Trypsin inhibitor

iii) buffer $\mathrm{C}: 50 \mathrm{mmol} / l$ HEPES pH $7.4,2 \mathrm{~mol} /$ $l \mathrm{KCl}, 1 \mathrm{~g} / l$ Emulgen $109 \mathrm{P}, 50 \mu \mathrm{mol} / l \mathrm{PMSF}, 2$ $\mathrm{mg} / l$ Trypsin inhibitor

iv) buffer $\mathrm{D}: 50 \mathrm{mmol} / l$ HEPES $\mathrm{pH} 7.4,0.5$ $\mathrm{mol} / l \mathrm{NaSCN}, 1 \mathrm{~g} / l$ Emulgen $109 \mathrm{P}, 50 \mu \mathrm{mol} / l$ PMSF, $2 \mathrm{mg} / l$ Trypsin inhibitor

溶出終了後は apo-Tf-Sepharose となっているため Fe-NTAによる鉄負荷を行い diferric Tf-Sepharose に変えて保存し, 次回の実験に利用した。

5) High pressure liquid chromatography (HPLC) TSK-G 3,000 SW カラムを用い, $25 \sim 100 \mu l$ の試料 （Tf-R, Tf : Tf-R Complex）を注入した. $50 \mathrm{mmol} / l$ HEPES, $0.3 \mathrm{~mol} / l \mathrm{KCl}, 0.1 \mathrm{mmol} / l$ dithiothreitol, $1 \mathrm{~g} / l$ Emulgen $109 \mathrm{P}$ を緩衝液と使用し, $1 \mathrm{~m} l / \mathrm{min}$ の 流速で実施しカラムより流出するタンパク質を 280 $\mathrm{nm}$ における吸光度にて追跡した。 また，Tf-R 調製用 として，流出液を $1 \mathrm{~m} l$ ずつに分取した，分子量は， high molecular weight standard mixture を用いて作 成した検量線より決定した。

6) Sodium dodecylsulfate polyacrylamide gel electrophoresis (SDS-PAGE)

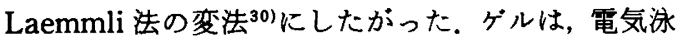
動用グラシェントゲル SDS-PAGE プレート 4/20を 使用した。還元条件での試料処理は，1\%SDS， $5 \% 2$ メルカプトェタノールを含む試料を $100^{\circ} \mathrm{C} て ゙ 2$ 分間加 熱処理した。ゲルの染色は, クマシーブルーにて行っ た.

7) Western blotting

SDS-PAGEを行い, ニトロセルロース膜に転写後, 抗 Tf-Rモノクロナール抗体を反応させた. その後, Anti-mouse Ig-G biotin conjugate, Avidine-labeled horseradish peroxidaseを反応させ $3,3^{\prime}$. diaminobenzidine (tetrahydrochloride) との反応に よって可視化した.

8）HPLCによる精製 Tf-R 分画の Tf 結合能の評 価

精製 Tf-R 分画の Tf との捊置の有無による HPLC 流出バターンの相違を比較検討した.

(i) buffer Cょり容出した Tf-R 分画 (tetramer) の $\mathrm{Tf}$ 結合能の評価

buffer Cょり容出した Tf-R 分画の Tf-R 分画単独
$50 \mu \mathrm{g}$ およびこの Tf-R 分画 $35 \mu \mathrm{g}$ と Tf $85 \mu \mathrm{g}$ との混 合物を室温で 30 分間捊置後, それぞれ別々に HPLC 分析を行った。

（ii）Buffer Dより溶出したTf-R 分画の Tf 結合 能の評価

Buffer Dより溶出した Tf-R 分画単独 $25 \mu \mathrm{g}$ および この Tf-R $25 \mu \mathrm{g}$ と Tf-100 $\mu \mathrm{g}$ との混合物を室温で 30 分間粰置後，それぞれ別々に HPLC 分析を行った.

9）トリプシンによるタンバク分解26,34)

Buffer C，Dょり溶出した Tf-R 単独およびそれぞ れの Tf との複合体をCentricon 30 (Amicon) にて濃 縮し, $50 \mathrm{mmol} / l$ HEPES pH 5.5 および 7.4 で希勫 し，pH 5.5 および 7.4 の試料を作製した。 pH 5.5 お よび 7.4 のそれぞれの試料にトリプシンをモル比が $1 ： 2$ になるように添加し, 氷冷中で 30 分間穊置した 後,トリプシンに対して 100 倍過鄱の PMSF を加え反 応を停止させ, SDS-PAGE 分析を行った。

\section{結 果}

\section{Tf-R の精製}

$160 \mathrm{~g}$ のヒト胎盤より約 $4 \mathrm{mg}$ の精製 Tf-R を得た. 上述のように Tf-Rの精製は，ヒト胎盤よりアセトン パウダーの作製, 可容化, Tf-Sepharose affinity chromatography の 3 段階より成っている.

Fig. 1 に diferric Tf-Sepharoseカラムの溶出ハ ターンを示した。すず，三価鉄と強い親和性を有する キレート鼡である desferrioxamine を含むbuffer A にてTfをアポ化すると鉄の放出が起こり，淡紅色の カラムが白色に変化した。この時, カラム流出液に大 きなピークが出現したが，このピークには小量のタン パクしか含有していないため，カラムから遊出した三 価のクエン酸鉄が主体をなすと思われた。ついで buffer Bにて液性を中性に戻すと小さなピークが認め

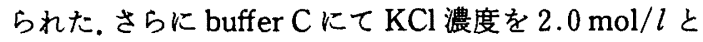
上昇させると大きなピークが出現した．引き続き 0.5 $\mathrm{mol} / l \mathrm{NaSCN}$ を含むbuffer Dにてもピークが認め られた。

Fig. 2 は, buffer A, Bに引き続き, buffer $\mathrm{C} の \mathrm{KCl}$ 濃度を $0.1 \mathrm{~mol} / l$ から $3.0 \mathrm{~mol} / l$ までグラジェントを 負荷した場合の溶出パターンを示した. $1.0 \mathrm{~mol} / l$ 以 上の濃度においても吸着タンパク質の溶出が認められ た。従来の報告 ${ }^{25}$ に用いられた溶出液の $\mathrm{KCl}$ 濃度が $1.0 \mathrm{~mol} / l$ となっているが，この濃度ではタンパクの 溶出が不完全であることが明らかとなった。よって著 


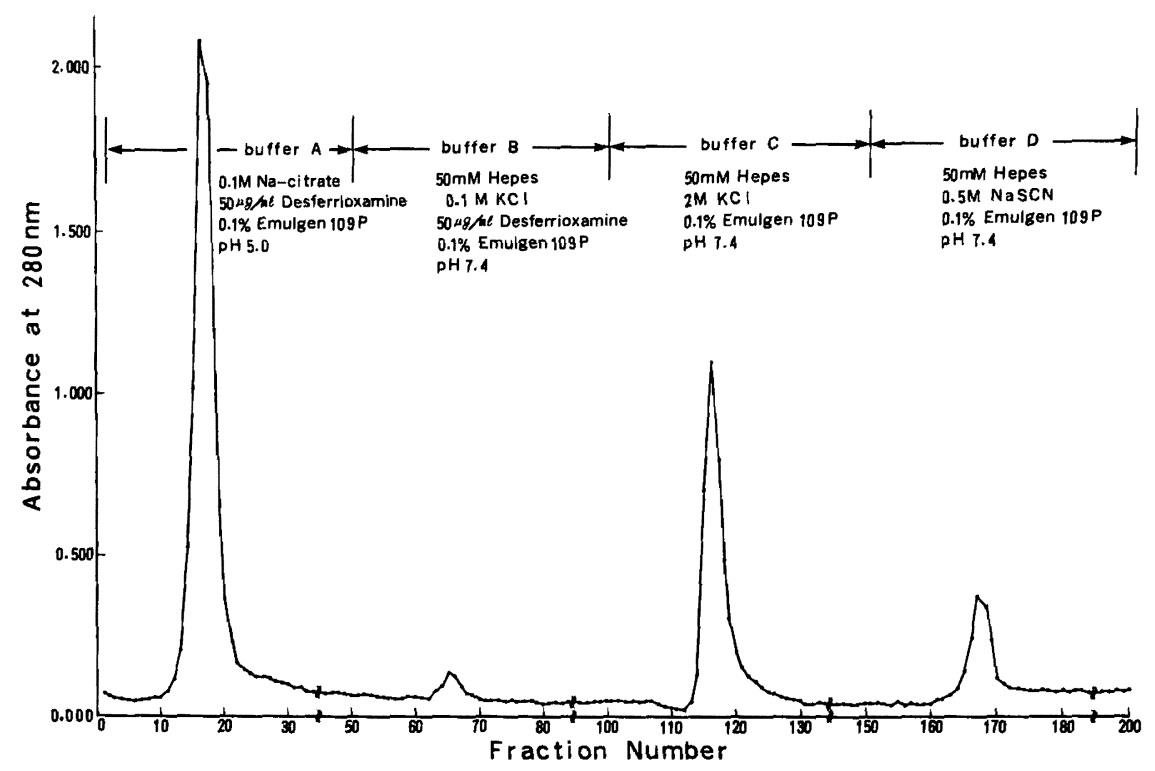

Fig. 1 Elution of proteins bound to a diferric Tf-Sepharose column Acetone powder extract was incubated with diferric Tf-Sepharose for $1 \mathrm{hr}$ at room temperature and then poured into a column. After washing the column with $50 \mathrm{mmol} / l$ HEPES buffer, proteins were eluted in four sequential buffers and a fraction of $2.5 \mathrm{ml}$ was collected and the absorbance at $280 \mathrm{~nm}$ was measured

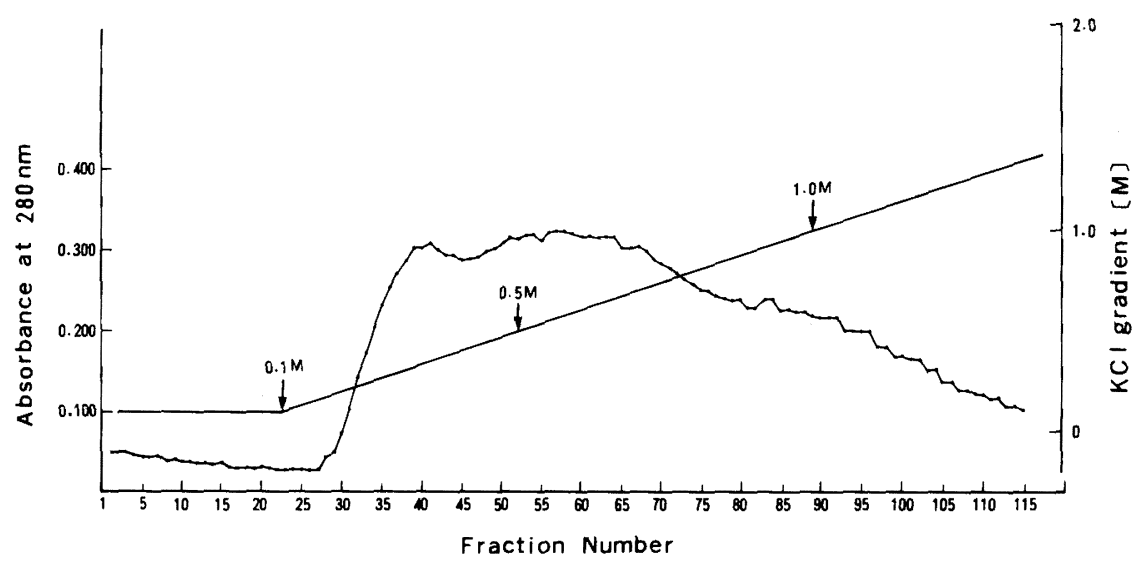

Fig. 2 Elution pattern of transferrin receptor from diferric Tf-Sepharose column with buffer $\mathrm{C}$ containing $\mathrm{KC} 1$ gradient

After elution of proteins with buffer $\mathrm{A}$ and $\mathrm{B}$, the column was applied with buffer $\mathrm{C}$ containing $\mathrm{KCl}$ gradient $(0.1 \sim 3.0 \mathrm{~mol} / l)$

者は, buffer $\mathrm{C} の ~ \mathrm{KCl}$ 濃度を $2.0 \mathrm{~mol} / l$ とした。

Fig. 3 は, フセトンパウダーの可溶化抽出液および affinity chromatography $の$ buffer B，C，Dより溶出 したタンパクの SDS-PAGEを示した。 アセトンパウ ダーの可溶化抽出液 (Ext) では, きわめて多数のバン

\section{ドが認められた。}

Buffer B 流出液（B）に認められるバンド（分子量； 80-kDa)は, 免疫電気泳動法により Tfであることを確 認した. buffer CおよびDの流出液 (C)および(D)) では, 還元状態で 90-kDa, 非還元状態で 180-kDa が主 


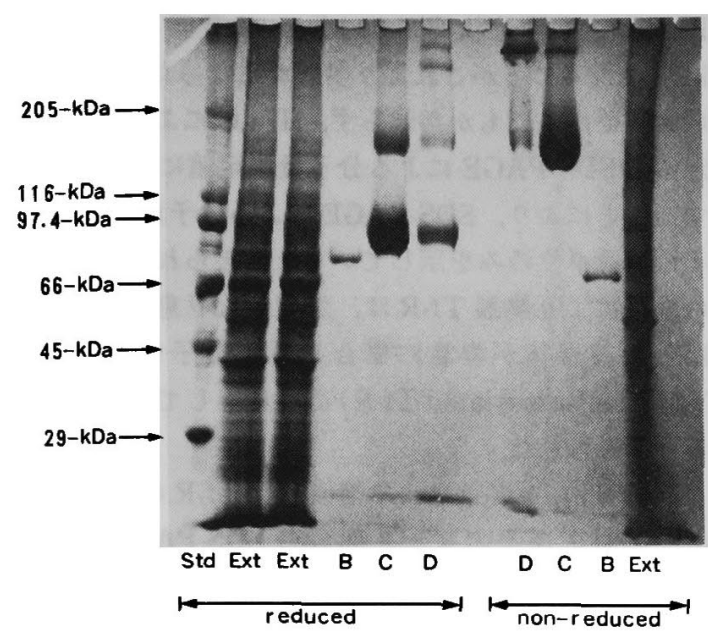

Fig. 3 Gradient SDS-PAGE $(4 \sim 20 \%)$ analysis of four protein fractions obtained from diferric Tf-Sepharose column

Each sample was concetrated to $7 \mathrm{mg} / \mathrm{ml}$ using a Centricon 30 apparatus (Amicon) and incubated with $1 \% \operatorname{SDS}(\mathrm{W} / \mathrm{V})$ in the presence (reduced) or abcence (nonreduced) of $5 \% 2$-mercaptoethanol (W/V) at $100 \mathrm{C}$ for 2 min. Lane Ext is acetone powder extract; Lane $\mathrm{B}, \mathrm{C}$ and $\mathrm{D}$ are proteins eluted with buffer $\mathrm{B}, \mathrm{C}$ and $\mathrm{D}$ respectively. Proteins concentration applied to each gel are as follow: Std $(5 \mu \mathrm{g})$, Ext $(15 \mu \mathrm{g}), \mathrm{B}(2 \mu \mathrm{g}), \mathrm{C}$ $(15 \mu \mathrm{g}), \mathrm{D}(10 \mu \mathrm{g})$. Lane Std is a mixture of myosin $(205-\mathrm{kDa}), \beta$-galactosidase (116$\mathrm{kDa})$, phosphorylase $B(97.4-\mathrm{kDa})$, bovine serum albumin $(66-\mathrm{kDa})$ ovabumin $(45-\mathrm{kDa})$ and carbonic anhydrase (29-kDa). Protein bands were visualized by staining with Coomassie Blue.

なバンドとして認められた. (C)，(D)の還元状態で認 められる 180-kDa のバンドは，還元剤を使用したのに も拘らず，タンパク量が多量のため還元されずに残っ たバンドと考えられた。すなわち，流出液 (C)，(D) とも, 少量負荷した場合には還元状態で, 90-kDa のバ ンドのみが羿められた。 そのほか流出夜 (C), (D) で は, 70-kDa の位置および高分子領域にも小さなバンド が認められた。

Fig. 4 は，抗 Tf-Rモノクロナール抗体 OKT 9 を 用いた Western blotting の結果である。 buffer Cおよ びDにて流出したすべてのタンパク質（Fig. 3 (C, D))は，OKT 9 と反応した。すなわち，(C)，(D)の 還元状態で認められる 90-kDa のバンドは, Tf-Rの一 量体，非還元状態で認められる 180-kDaのバンドは

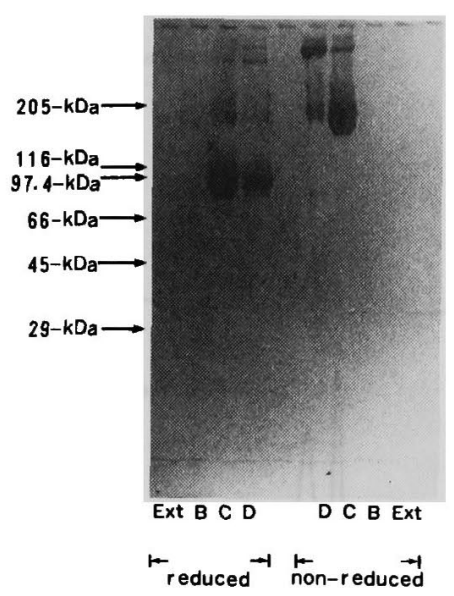

Fig. 4 Western blotting of the gradient SDS-PAGE The proteins separated by SDS-PAGE (Fig. 3) were transferred to a nitrocellulose membrane and reacted with anti-Tf-R monoclonal antibody OKT $9(5 \mu \mathrm{g})$ for $2 \mathrm{~h}$ at room temperature. After incubating with anti-mouse Ig-G biotin conjugate and avidine-labelled horseradish peroxidase, the membrane was finally reacted with $3,2^{\prime}$. diaminobenzidine (tetrahydrochlorine) to visualize proteins.

Tf-Rの二量体であることを免度学的に確認した。 70-kDa の小さなバンドは, Turkewitz ら ${ }^{26.34)}$ が報告し ているTf-Rの extracellular fragment と想像され た。をた，アセトンパウダーの可溶化抽出液は, 理論 上OKT 9 と反応するバンドがあるはずだが検出され なかった。それれ Tf-Rの相対濃度が低いためと考之 られた，Buffer B からの流出液（B）は無反応であっ たが，この現象は（B)の含有するタンパク質が Tf で あることを示すものである. 一方，抗 Tf-Rモノクロ ナール抗体 NU-tfR1 を用いてWestern blotting を実 施しても，OKT 9 と全く同様な結果が得られた。

\section{HPLCによる精製 Tf-Rの分子量的検討}

TSK-G 3,000 SW カラムを用い，精製 Tf-R の分子 量的検討を加光た. buffer Cより溶出したTf-Rの TSK-G 3,000 SW gel filtration HPLC の流出パター ンお上びそれぞれのピークの部分の SDS-PAGE(還 元状態)をFig. 5 に示した。最も典型的なパターンが 最上段で, HPLCにおける分子量は 370-kDaであっ た.二量体の重合体として存在すると想像されたが, SDS-PAGEの結果よりその構成単位は 90-kDa の一 量体であることを確認した。 また時に認められるのが 


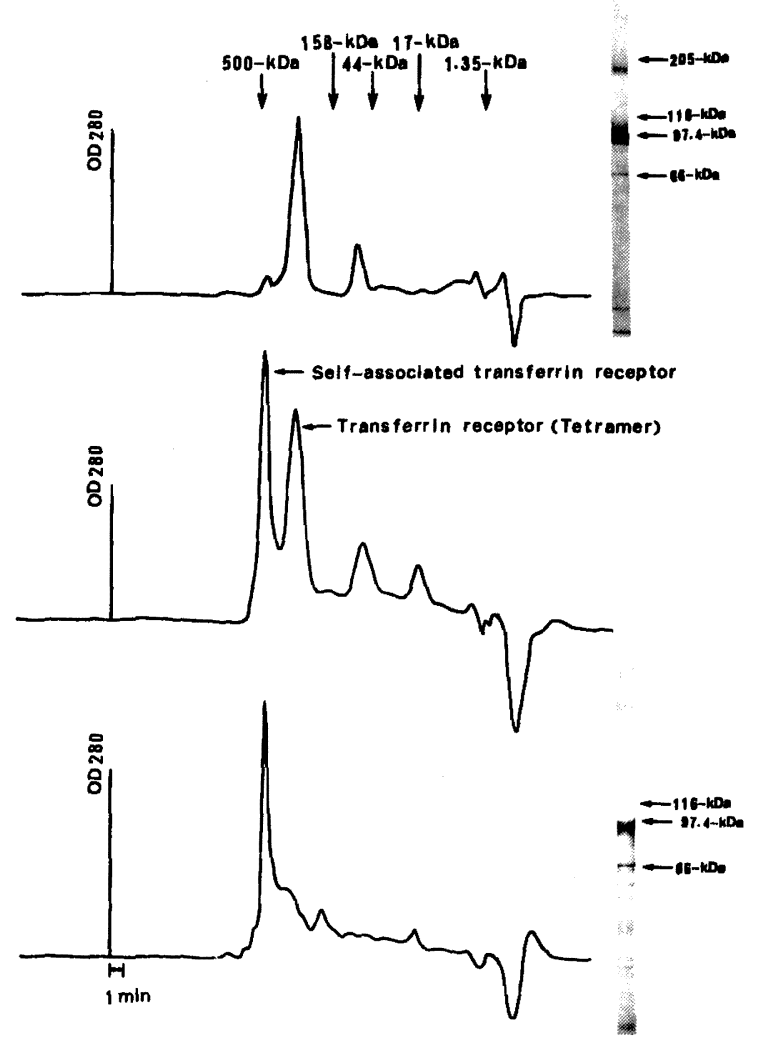

Fig. 5 Gel filtration (HPLC) patterns of $T f-R$ obtained from buffer $\mathrm{C}$

Gel filtration (HPLC) on a TSK-G 3,000 SW column was performed in $50 \mathrm{mmol} / l$ HEPES $\mathrm{pH} 7.4$ containing $0.3 \mathrm{~mol} / l \mathrm{KCl}, 0.1 \mathrm{mmol} /$ $l$ dithiothreitol and $1 \mathrm{~g} / l$ Emulgen $109 \mathrm{P}$ at a flow rate of $1 \mathrm{ml} / \mathrm{min}$ and $1 \mathrm{ml}$ fractions were collected. Three elution patterns were obtained and fraction of each major peak was concentrated to $1 \mathrm{mg} / \mathrm{ml}$ using a Centricon apparatus. These samples were analysed by gradient SDS-PAGE in reduced condition as described in the experiment of Fig. 3. Arrows indicate molecular weight standards : thyroglobulin $(670-\mathrm{kDa})$. gamma globulin (158-kDa), ovabumin $(44-\mathrm{kDa})$, myoglobin $(17-\mathrm{kDa})$, vitamin $\mathrm{B}_{12}$ (1.35$\mathrm{kDa}$ ).

最下段のパターンで HPLCの void volume の位置に 出現し，二量体の複合体と思われたが，これもSDSPAGEょりその構成単位は90-kDaの一量体であっ た。 中段に認められるパターンは，両者の移行像を示 していた。このように Tf-Rが四量体として存在して む，さらに二量体の複合体として存在しても SDS.
PAGEでは還元状態で 90-kDa，非還元状態で 180kDaになることがこれより明らかになった．同一タン パク質であるにもかかわらず，HPLCによる分子量測 定値とSDS-PAGEによる分子量測定値に相異が存在 することにより，SDS-PAGEによる分子量測定值は， その構成単位のみを示していると考えられた。これら の結果により精製 Tf-Rは，生理的な状態では，180$\mathrm{kDa}$ の複合体が容易に集合し巨大分子を形成した Tf-R (self-associated Tf-R) の状態として存在してい ると示唆された。

Fig. 6 に, buffer Dより溶出した Tf-Rの HPLCハ ターンおよびそのピーク部分の SDS.PAGEを示し た. Buffer Cの場合とは異なり buffer Dより溶出する Tf-R はすべて void volumeの位置に出現し四量体は 認められなかった。この場合もSDS-PAGEの結果よ ク, その構成単位はすべて 90-kDa の一量体であった。

\section{HPLCによる精製 Tf-R の Tf 結合能の評価}

精製 Tf-R と Tf complex を形成させ，Tf-R の複合体形成に伴ら分子 量の増加を gel filtration HPLCにて検討した。

Fig. 7 に四量体の Tf-R 単独とこの Tf-Rを diferric Tf と眯置後, HPLC 分析した結果を示した. 実線 で四量体の Tf-R 単独, 点線で Tf 之孵置後の流出ハ ターンを図示した，Tf との睬置により Tf-R 単独時に 認められたピークは完全に消失し，高分子領域に新た なピークおよびTfの retention timeに相当するピー クを認めた。 すなわち，精製 Tf-R 分画は，Tf と反応 し Tf: Tf-R complex 形成したものと考えられた。 また Tf-R 単独時に認められたピークが完全に消失し ていることより結合活性をはぼ完全に維持しているも のと考えられた。

ついで HPLCにて void volumeの位置に認められ た self-associated Tf-Rの結合活性を検討した。実線 でTf-R 単独, 点線でTf と睬置後の流出パターンを Fig. 8 に示した. ただし，TSK-G 3,000 SW（排除限 界分子量 $500 \cdot \mathrm{kDa}$ )では void volume の位直に selfassociaed Tf R 自身のピークが出現するため，Tf と の結合により分子量が增加してもbuffer Cより流出 したTf-Rに認められたような retention timeの短維 (Fig. 7) としては観察されえない.そのため Tf-R 単 独時のタンパク量とTfと偁置した Tf-Rの終濃度を 同一にし, その他の測定条件を変化させずに void volume の位置に認められるピーク高を比較した. self- 


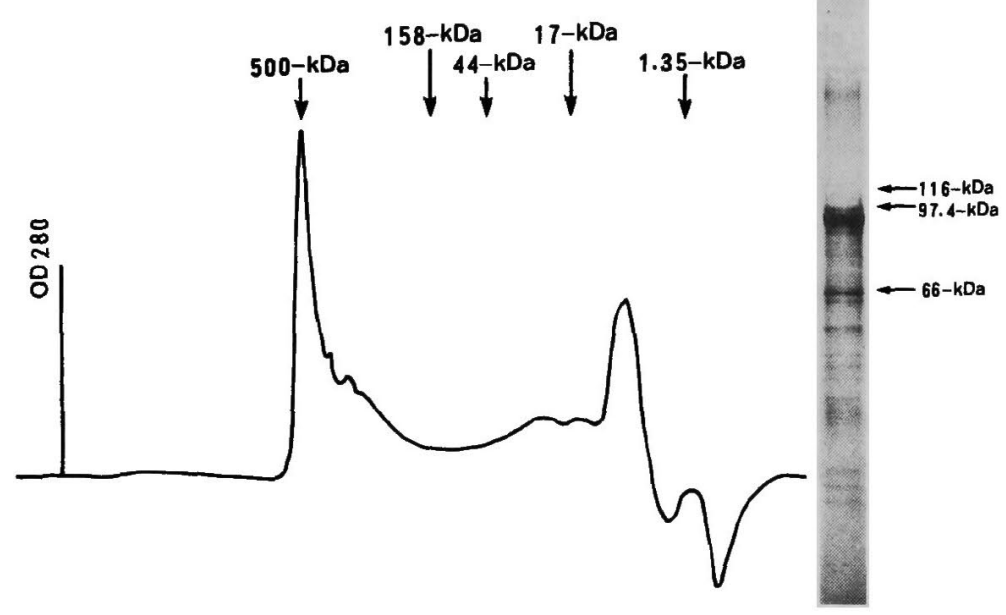

Fig. 6 Gel filtration (HPLC) pattern of Tf-R obtained from buffer D Experiment was carried out by the same condition as in Fig. 5.

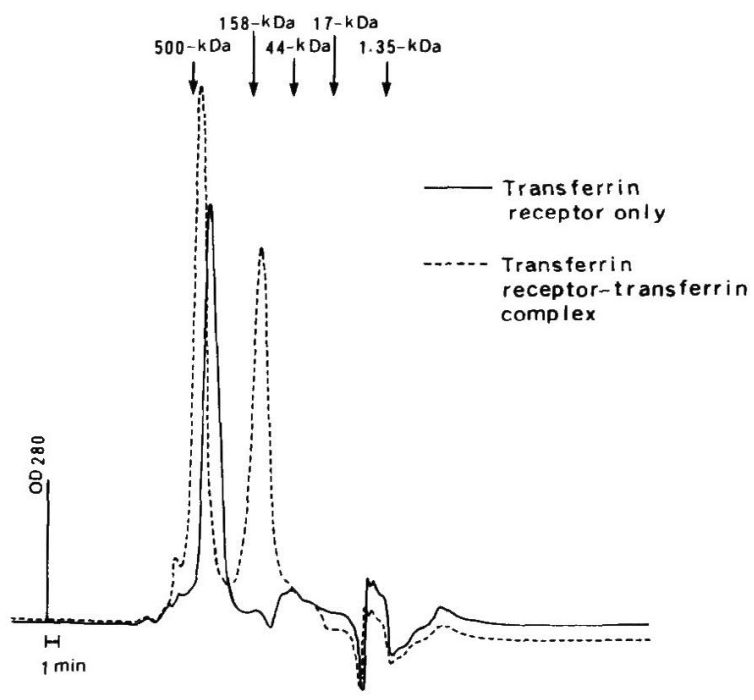

Fig. 7 Gel filtration (HPLC) pattern of $\mathrm{Tf}-\mathrm{R}$ and Tf: Tf-R complex eluted with buffer $C$ Gel filtration (HPLC) was performed under the same condition as in Fig. 5. Solid line representes the pattern of $\mathrm{Tf} \cdot \mathrm{R}(50 \mu \mathrm{g})$. Broken line represents the pattern of a mixture of Tf-R $(40 \mu \mathrm{g})$ and $\mathrm{Tf}(80 \mu \mathrm{g})$, incubated $1 \mathrm{~h}$ at $37^{\circ} \mathrm{C}$ prior to the analysis.

associated Tf-R と Tfを睜置することにより，Tf-R 単独の場合のピークと比較して,ピーク高の顕著な増 加が認められた。これより TSK-G 3,000 SW の void

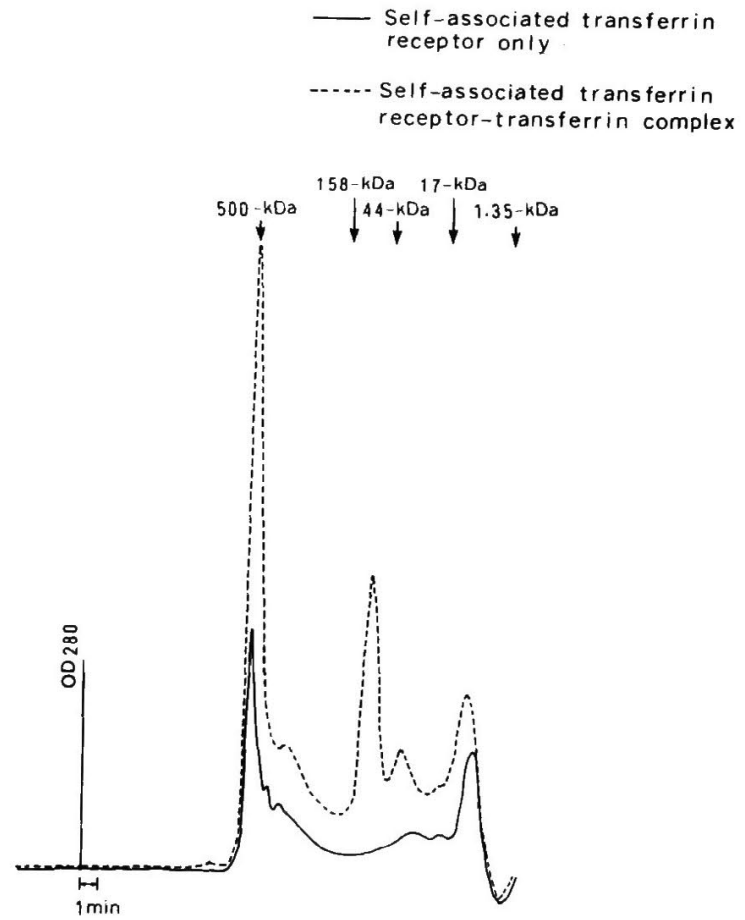

Fig. 8 Gel filtration (HPLC) pattern of Tf-R and Tf : Tf-R complex eluted with buffer $D$ Experiment was carried out under the same condition as described in Fig. 5. Solid line represents the pattern of Tf-R $(25 \mu \mathrm{g})$. Broken line represented the pattern of a mixture of Tf-R $(25 \mu \mathrm{g})$ and $\mathrm{Tf}(100 \mu \mathrm{g})$, incubated for $1 \mathrm{hr}$ at $37^{\circ} \mathrm{C}$ prior to the analysis. 
Trypsin (-)

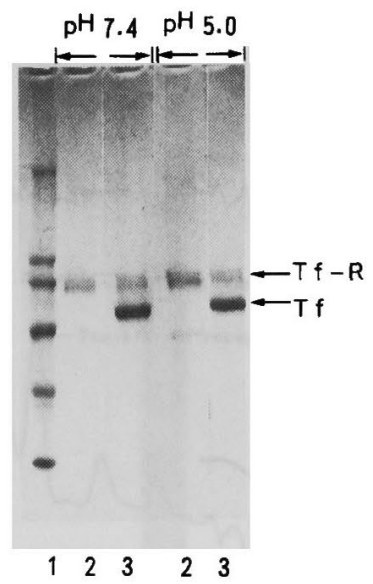

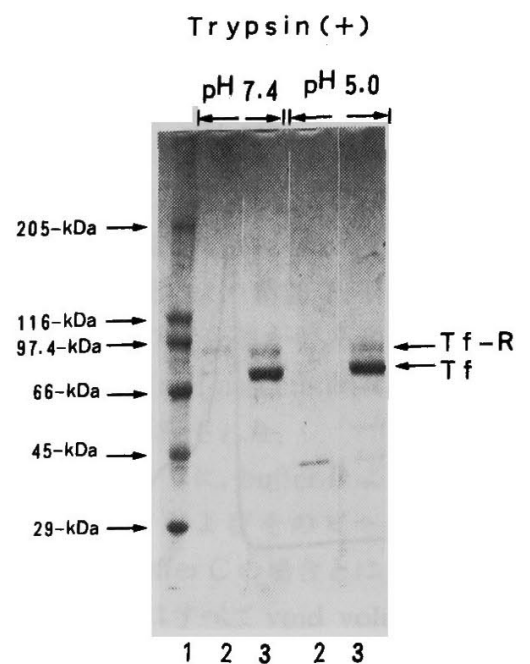

Fig. 9 Gradient SDS.PAGE $(4 \sim 20 \%$ ) of trypsin digested Tf-R eluted with buffer C and Tf: Tf-R complex

After incubating Tf-R $(50 \mu \mathrm{g})$ and $\mathrm{Tf} 100 \mu \mathrm{g})$ in HEPES buffer $\mathrm{pH} 7.4$, the complex was concentrated to $10 \mathrm{mg} / \mathrm{ml}$ and was diluted $1: 10$ in HEPES buffer $\mathrm{pH} 7.4$ or 5.5 . A trypsin: Tf-R (1:2 molar ratio) was employed and proteolysis was carried out for $30 \mathrm{~min}$ on ice. The reaction was terminated by adding PMSF. Lane 1 (molecular weight standard) : Lane 2 (Tf-R) : Lane 3 (Tf : Tf-R complex).

Trypsin(-)

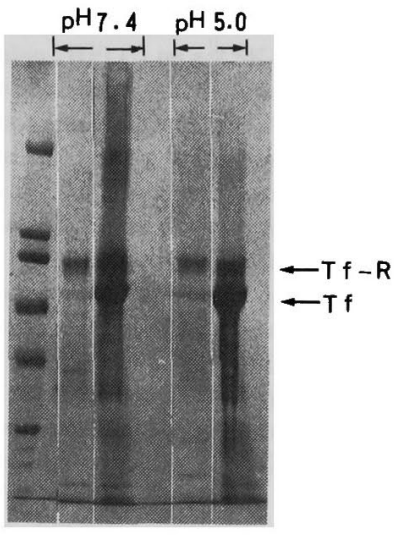

$\begin{array}{lll}1 & 2 & 3\end{array}$

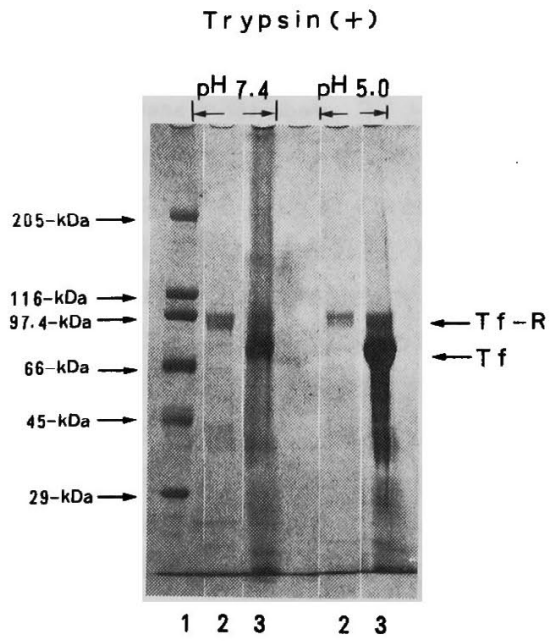

Trypsin (+)

Fig. 10 Gradient SDS-PAGE (4 20\%) of trypsin digested Tf-R eluted with buffer D and its Tf: Tf-R complex

The experiment was carried out under the same condition as described in Fig. 10. Lane 1 (molecular weight standard): Lane 2 (Tf-R): Lane 3 (Tf : Tf-R complex).

volume の位置に認められるTf-R Tf との結合活 性を有し Tf：Tf-R complex を形成したものと考觉ら れた。

\section{4. トリプシン消化による精製 Tf-R 分画の安定性 の検討}

Turkewitz ら $^{35)}$ は, 70-kDa の Tf-R (extra-cellar 
fragment)抌よびTf との complex の消化酵素に対す る安定性を検討し, complexの形成ならびに selfassociationにより安定性が增大すると報告している。 そこで，Tf-R（四量体；buffer Cょり容出), selfassociated Tf-R (buffer Dより溶出) およびそれぞれ の Tf-R: Tf complex をトリプシン消化し，トリプシ ン消化の前後における SDS-PAGE 像の相違を比較す ることによりその安定性を検討した．Fig.9 は，四量

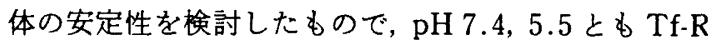
単独では分解されてしまらが, complexを形成するこ とによりトリプシンに対する抵抗性の增大が認められ た。また, self-associated Tf-Rは, pH 7.4, 5.5 とも トリプシン消化を受けず安定であり，なおかつ com plex b $\mathrm{pH} 7.4,5.5$ ともトリプシン消化を受けず安定 であった（Fig. 10）。以上の結果から Tf-Rは，complex の形成および self-association により安定化がは かられると考えられた。

\section{考 察}

Tf-Rに関する研究の歴史は古く, 1963 年, Jandl and $\mathrm{Kat}^{31}{ }^{31}$ が immature red cell を用いてTf-Rの存 在を示咬したのがそのはじまりである，以来，多数の 研究が報告されているが，Tf-R の精製についての歴史 は浅く, 1979 年の Seligman ら ${ }^{199}$ の報告が最初である。 しかし，収量が悪く，操作がきわめて複雑であるらえ に活性が低いなどの欠点が指摘され, 1986 年, Ander son ら ${ }^{251} に よ り$ 簡略化した精製方法が報告された。彼 らの精製方法の特徵は, Tf-R および Tf の持つ生化学 的特徵を精製に応用した点である。すなわち，Tf-R と Tf の親和性は, diferric-Tf, monoferric-Tf, apo-Tf の順に低下すること,および Tf-R と complexを形成 している diferric-Tf 弱酸性下でフポ化しても，Tf$\mathrm{R}$ と apo-Tf は解離せず，液性が中性になって初めて 両者の解離が生しるるいら特徵を利用してTf Sepharose カラムから Tf-R を溶出させた点である。 そして，この精製方法をさらに改良したのが Turkewitz ${ }^{26)}$ でり, 内因性 TfKよる affinity chromatography の競合現象の除去 (iron chelation), およびTf-Sepharose カラムの溶出条件をさらに改善 した，前記した 3 者に共通していえるのは，胎艋の洗 浄, 可溶化, 硫安沈渣, 透析, affinity chromatography という段階を経ていることである。しかし，胎盤はき わめて血液を豊富に含む組織であるため，多量の胎盤 を短時間に洗浄し血液成分を完全に除去するのは困難
である。そのため内因性のTfが残り affinity chromatography の収量を下げる原因に成ると考党ら れる.また，多量の胎盤を完全に可溶化することはきわ めて難しく，そのため多量の胎盤を使用したにも拘ら ず，結果的には少量の胎盤しか可溶化されていないと 考学られた.このような欠点を改善するため, 著者は長 期保存が可能であるアセトンパウダーを利用した．す なわち，胎盤ホモジェネートのアセトンパウダーから 出発することにより，胎盤の洗浄が不十分で血液が残 存する試料であっても，フセトンパウダーを溶媒で洗 浄することによって胎盤成分から血漿成分(血漿 Tf を含む）を分離可能とした。 た, $160 \mathrm{~g}$ の胎盤は約 30 gのアセトンパウダーを作るため，可溶化の効率が上 げられると考えられた，同時にアセトンパウダーを利 用すれば，硫安沈渣を省略しても Tf-R の精製が可能 であることが示された。ささらに著者の精製方法の特徵 は, Tf-Sepharose カラムの再利用が可能である点であ る.従来の報告では Tf-Sepharose カラムは, 再利用は 不可能とされてきたが, 鉄負荷に Fe-NTA を利用する ことにより再利用が可能と成った。 な, rat kidney, reticulocyte, myeloma cell, erythroleukemic cell を 検体としてTf-R の精製の報告 ${ }^{21,32,33)}$ があるが, 解剖学 的にも Tf-R が豊富に存在し，しかも入手しやすい胎 盤が精製材料として最も適していると思われた。

従来 Tf-R の分子量に関する考察は, SDS-PAGE に 依存してきた. 1982 年, Schneider $5^{13)}$ は, 抗 Tf-R モ ノクロナール抗体 OKT 9 を用いた immunoprecipitationにより，Tf-Rは90-kDaの一量体の disulfidelinked homodimerであると報告している。彼らも SDS-PAGEを利用しており, gel filtrationにより Tf$\mathrm{R}$ の分子量に関する考察を加えている報告はきわめて 少ない. 1988 年, Turkewitz らはTf-R の精製に成功 し，精製 Tf-Rの分子量は gel filtrationにより四量体 $(\mathrm{Mr}=420-\mathrm{kDa})$, 二量体 $(\mathrm{Mr}=190-\mathrm{kDa})$ であると 報告しているが，他方 SDS-PAGEではすべて 90-kDa の一量体(還元状態)，180-kDa の二量体(非還元状態) であると報告している ${ }^{26)}$.このよ5に同一物質であり ながらす gel filtration と SDS-PAGEでは分子量に違 いがあることを示している。これは著者の実験結果 (Fig. 5, 6)を支持するものであり, SDS.PAGEでの 分子量が必ずしも生理的な状態での分子量を反映して いるとは限らないと示㖫された，そのため彼らは，同 年, Tf-Rの self-associationの概念を導入した ${ }^{34)}$. Tf-Rをトリプシン処理して生ずる 70-kDa の frag. 
ment は, pH 依存性の self-association を受けること を HPLC および電子顕铛鏡的所見により証明した。 self-associationのメカニズムについては全く不明で あるが著者の実験系においては，可溶化された Tf-R とTfがカム内で receptor 結合することによって, あるいは diferric Tf-sepharoseがアポ化された段階 で同様の self-association が生じ，これがカラムより 溶出したものと考兄られた。著者は, Tf-Rの selfassociation により, endosome内に多数の Tf：Tf-R complexを包含できれば receptor-mediated endocytosis が効率良く行われ, 生体にとって合目的と 考えている.しかし,一つの clathrin-coated vesicle $の$ 中に一分子の Tf-Rのみを含み, 可溶化されてはじめ て self-association が起こるといら報告35) あり, ア セトンパウダーの可溶化溶液の段階で selfassociation が起こる可能性もある.たたし，この報告 においては, 細胞膜に存在するすべての clathrincoated vesicleについて検討しているわけではないば かりか, Tf-R に特異的な clathrin-coated vesicle であ るといら証明もない:そのため他の receptor の clathrin-coated vesicle も含まれている可能性もあ り, 実際に clathrin-coated vesicle 中に含まれる Tf-R 数より少なく計算している可能性がある.いずれにせ よ, 今後の研究課題として残された問題である.

Receptor-mediated endocytosisは, Tfに特有な ligand 取り込み機構ではなく, insulin, asialoglycoprotein, low density lipoproteinなどでも報告5され ている. Endosome 内の $\mathrm{pH}$ が specific proton pumps により酸性に転換すると, レセプターとリガンド間の 結合は解離され，そのためこのような endosomeを CURL (compartment of uncoupling of receptor and ligand）と呼ばれている.しかし，Tfの場合にはこの ような解離は起こらずTf: Tf-R complexを形成した ままである。このようにして細胞内に取り込まれたレ セプターとリガンドがライソン゙ームなどの細胞内消化 酵素により分解されてしまう場合と分解されずに細胞 表面に recycle される場合が起こり得る. Tf の場合は 後者に属するが, この両者の違いを支配する因子は全 く不明であるか，著者の実験結果から Tf：Tf-R 複合 体および self-associated Tf-Rのトリプシンに対する 抵抗性より何らかの関与が示唆された. Receptormediated endocytosis のどの段階で，またどのような 部位で self-associationを起こすかは不明であるが, endosome内ではTf: Tf-R complexがself. associationの状態となる可能性もある.そこで Tf-R および complex の安定性をトリプシン消化によって 検討したところ Tf-Rは, complex の形成および selfassociation によって安定性の増大が認められるとい 5結論を得た。すなわち，Tf-R は self-association に よって安定化するため細胞内消化酵素の分解を受ける 割合が少なく recycleすると考えられた。

\section{結 論}

1）ヒト胎盤からアセトンパウダーを作製し, Emulgen $109 \mathrm{P}$ 抽出後, Tf-Sepharose に対する親和性を利 用してトランスフェリン・レセプター（Tf-R）を精製 した.

2）精製 Tf-R 分画は, SDS-PAGE で 90-kDa（還元 条件)，180-kDa（非還元条件）であった。

3) Gel filtration では, 四量体 (Mr $370-\mathrm{kDa})$, さ らにその複合体として存在した。

4）抗 Tf-Rモノクロナール抗体 OKT 9, NU-tfR1 を用いWestern blottingを行うとクマシーブルーで 染色されるすべてのバンドが反応性を示した.

5）精製 Tf-R 分画のTf との結合性活性を, Gel filtrationより確認した。

6）精製 Tf-R 分画の安定性をTrypsin 消化により 検討すると Tf：Tf.R complex の形成, およびSelfassociationにより安定性の増大が認められた。

稿を終わるに臨み，直接ご指導いただきました生化学第 2 教室 吉野芳夫主任教授，平井幸彦博士，ならびに教室員各位に深く感 謝いたします。また, Emulgen 109 P, OKT 9 をご提供いたたき ました花王 (株), Orth Diagnostic System 社の両社に深く感謝 いたします。

なお, 本論文の要旨は第 62 回日本生化学会大会(1989 年 10 月) において発表した.

\section{文 献}

1) Karin, M. and Mintz, B.: Receptor-mediated endocytosis of transferrin in developmentally totipotent mouse teratocarcinoma stem cells. J. Biol. Chem., 256, $3245 \sim 3252,1981$.

2) van Renswoude, J., Bridges, K.R., Harford, J.B. and Klausner, R.D. : Receptor-mediated endocytosis of transferrin and the uptake of $\mathrm{Fe}$ in $\mathrm{K} 562$ cells ; Identification of a nonlysosomal acidic compartment. Proc. Natl. Acad. Sci. USA, 79, 6186 6190, 1982.

3) Lamb, J.E., Ray, F., Ward, J.H., Kushner, J.P. and Kaplan, J.: Internalization and subcellular localization of transferrin and transferrin receptors in HeLa cells. J. Biol. Chem., 258, 8751 8758, 1983.

4) Ciechanover, A., Schwartz, A.L., Dautry-Varsat, A. and Lodish, H.F.: Kinetics of internalization and recycling 
of transferrin and the transferrin receptor in a human hepatoma cell line. J. Biol. Chem., 258, 9681 -9689, 1983.

5) Dautry-Varsat, A., Ciechanover, A. and Lodish, H.F.: $\mathrm{pH}$ and the recycling of transferrin during receptormediated endocytosis. Proc. Natl. Acad. Sci. USA, 80, $2258 \sim 2262,1983$.

6) Harding, C., Heuser, J. and Stahl, P.: Receptormediated endocytosis of the transferrin receptor in rat reticulocytes. J. Cell Biol., 97, 329 339, 1983.

7) Hopkins, C.R. and Trowbridge, I.S.: Internalization and processing of transferrin and the transferrin receptor in human carcinoma A431 cells. J. Cell Biol., 97, 508 521, 1983.

8) Klausner, R.D., Ashwell, G., van Renswoude, J., Harford, J.B. and Bridges, K.R.: Binding of apotransferrin to K562 cells; Explanation of the transferrin cycle. Proc. Natl. Acad. Sci. USA, 80, 2263 2266, 1983.

9) Klausner, R.D., van Renswoude, J., Ashwell, G., Kempf, C., Schechter, A.N., Dean, A. and Bridges, K.R.: Receptor-mediated endocytosis of transferrin in K562 cells. J. Biol. Chem., 258, 4715 4724, 1983.

10) Ajioka, R.S. and Kaplan, J. : Intracellular pools of transferrin receptors result from constitutive internalization of unoccupied receptors. Proc. Natl. Acad. Sci. USA, 83, 6445 6449, 1986.

11) Sutherland, R., Delia, D., Schneider, C., Newman, R., Kemshead, J. and Greaves, M. : Ubiquitous cell-surface glycoprotein on tumor cells is proliferation-associated receptor for transferrin. Proc. Natl. Acad. Sci. USA, 78, 4515 4519, 1981.

12) Enns, C.A. and Sussman, H.H.: Physical characterization of the transferrin receptor in human placenta. J. Biol. Chem., 256, 9820 9823, 1981.

13) Schneider, C., Sutherland, R., Newman, R. and Graves, M. : Structural features of the cell surface receptor for transferrin that is recognized by the monoclonal antibody OKT9. J. Biol. Chem., 257, 8516 8522, 1982.

14) Tycko, B. and Maxfield, F.R.: Rapid acidification of endocytic vesicles containing $\alpha 2$-macroglobulin. Cell, 28 , 643 651, 1982.

15) Marsh, M., Bolzau, E. and Helenius, A.: Penetration of Semliki Forest Virus from acidic prelysosomal vacuoles. Cell, 32, 931 940, 1983.

16) Nunez, M.-T. and Glass, J.: The transferrin cycle and iron uptake in rabbit reticulocytes. J. Biol. Chem., 258, 9676 9680, 1983.

17) Fielding, J. and Speyer, B.E. : Iron transport intermediates in human reticulocytes and the membrane binding site of iron-transferrin. Biochem. Biophys. Acta, 363 , 387 396, 1974.

18) Sullivan, A.L. and Weintraub, L.R.: Identification of ${ }^{125}$ I-labeled rat reticulocyte membrane proteins with affinity for transferrin. Blood, 52, 436 446, 1978.

19) Seligman, P.A., Schlicher, R.B. and Allen, R.H.: Isolation and characterization of the transferrin receptor from human placenta. J. Biol. Chem., 254, 9943 9946, 1979.

20) Wada, H.G., Hass, P.E. and Sussman, H.H.: Transferrin receptor in human placental brush border membrane.
J. Biol. Chem., 254, 12629 12635, 1979.

21) Fernandez-Pol, J.A. and Klos, D.J.: Isolation and chracterization of normal rat kidney cell membrane proteins with affinity for transferrin. Biochem. 19, 3904 -3912, 1980.

22) Stein, B.S. and Sussman, H.H.: Peptide mapping of the human transferrin receptor in normal and transformed cells. J. Biol. Chem., 258, 2668 2673, 1983.

23) Tsunoo, H. and Sussman, H.H.: Placental transferrin receptor. J. Biol. Chem., 258, 4118 4122, 1983.

24) Enns, C.A., Shindelman, J.E., Tonic, S.E. and Sussman, H. H.: Radioimmunochemical measurement of the transferrin receptor in human trophoblast and reticulocyte membranes with a specific anti-receptor antibody. Proc. Natl. Acad. Sci. USA, 78, 4222 4225, 1981.

25) Anderson, G.J., Mackerras, A., Powell, L.W. and Halliday, J.W.: Improved purification of the human placental transferrin receptor and a novel immunoradiometric assay for receptor protein. Biochim. Biophys. Acta, 884, 225 233, 1986.

26) Turkewitz, A.P., Amatruda, J.F., Borhani, D., Harrison, S.C. and Schwartz, A.L.: A high yield purification of the human transferrin receptor and properties of its major extracellular fragment. J. Biol. Chem., 263, 8318 8325, 1988.

27）吉野芳夫, 折茂英生, 久安早苗, 神成節子, 平井幸彦：卜ラ ンスフェリンと血清鉄. 続生化学実験講座, 第 8 巻, p. 461 ４68, 日本生化学会編, 1987.

28) Awai, M., Narasaki, M., Yamanoi, Y. and Seno, S. : Induction of diabetes in animals by parenteral administration of ferric nitrilotriacetate. Am. J. Path., 95, $663 \sim 674,1979$.

29) Hudgin, R.L., Pricer, W.E., Jr., Ashwell, G., Stockert, R.J. and Morell, A.G.: The isolation and properties of a rabbit liver binding protein specific for asialoglycoproteins. J. Biol. Chem., 249, 5536 5543, 1974.

30) Laemmli, U.K.: Cleavage of structural proteins during assembly of the head of bacteriophage T4. Nature, 227, $680 \sim 682,1970$.

31) Jandl, J.H. and Katz, J.H.: The plasma-to-cell cycle of transferrin. J. Clin. Invest., 42, 314 326, 1963.

32) Ecarot-Charrier, B., Grey, V.L., Wilczynska, A. and Schulman, H.M.: Reticulocyte membrane transferrin receptors. Can. J. Biochem., 58, 418 426, 1980.

33) van Driel, I.R., Stearne, P.A., Grego, B., Simpson, R.J. and Goding, J.W.: The receptor for transferin on murine myeloma cells; One-step purification based on its physiology, and partial amino acid sequence. J. Immunol., 133, 3220 3224, 1984.

34) Turkewitz, A.P., Schwartz, A.L. and Harrison, S.C.: A pH-dependent reversible conformational transition of the human transferrin receptor leads to self-association. J. Biol. Chem., 263, 16309 16315, 1988.

35) Turkewitz, A.P. and Harrison, S.C.: Concentration of transferrin receptor in human placental coated vesicles. J. Cell Biol., 108, 2127 2135, 1989. 